\title{
VOZES DE MULHERES DA ANTIGUIDADE: TRADUÇÕES DE DISCURSOS DE GRANDES PERSONAGENS FEMININAS DO DRAMA CLÁSSICO
}

WOMEN'S VOICES IN ANTIOUITY: TRANSLATIONS OF SPEECHES BY FEMININE CHARACTERS IN CLASSICAL DRAMA

TrupLit*

INTRODUÇÃO

À guisa de epígrafe, recorro aqui às palavras de Paulo Henriques Britto:

O verdadeiro poeta de meu tempo era uma espécie de engenheiro que, dentro de um programa estético coletivo, elaborava um projeto de obra e ia construindo poemas que realizassem na prática este projeto; os sentimentos individuais, as emoções, não tinham qualquer relevância para o trabalho do poeta. [...] Ao recriar num idioma diferente um *mpelluci@gmail.com

Universidade Federal de Minas Gerais.

Para o presente texto, constituiu-se a Trupe de Tradução do Pós-Lit (TrupLit), da Faculdade de Letras da UFMG, que aqui se mostra na seguinte formaçao: Carlos Eduardo de Souza Lima Gomes, Douglas Cristiano Silva, Felipe Coelho de Souza Ladeira, Marina Pelluci Duarte Mortoza, Nathalia Thomazella, Rafael Guimaraes Tavares da Silva e Vanessa Ribeiro Brandáo; cada um dos participantes atuou como responsável por um trecho traduzido, todos, porem, criticamente dos textos de seus colegas proponentes.

eu lírico que não o meu, eu estava, é claro, construindo uma persona poética, tal como eu fazia antes, quando escrevia meus próprios poemas e julgava estar exprimindo uma personalidade pré-existente. Ora, assim sendo, seria possível concluir que as duas atividades, a de escrever poesia de traduzir poesia, são essencialmente a mesma coisa. Em a mbas se dá a construção de um texto e de um sujeito textual com base em uma série de materiais pré-existentes. Se alguém lembrar que, no caso da tradução de poesia, o trabalho de escrita se faz em função de um texto pré-existente, 
1. BRITTO. Poesia: criação e tradução, p. 13. ao contrário do que ocorre na escrita de poesia, seria possível contra-argumentar que nem aí há uma diferença real Pois escrever poesia "original" ta mbém pressupõe a leitura de outros poemas. Como meu rela to a utobiográfico deixa claro, só pude escrever os poemas que vim a escrever por ter lido antes uma série de outros poemas de outros autores, e só pude elaborar uma persona poética com base nas personx que depreendi da leitura desses autores. Assim, os poemas em relação aos quais me coloco como a utor vieram a ser escritos em função de poemas anteriores, tal como os poemas em relação aos quais me coloco como tradutor foram criados em função de originais em inglês. Dentro dessa linha de raciocínio, nenhum texto é "original" em nenhum sentido verdadeiro do termo, e as supostas diferenças entre original e tradução não passam de reificações ideológicas. O sujeito lírico, ou o "sujeito" tout court, afinal, seria apenas um efeito do discurso, tal como o "significado", a "autoria" e mesmo a "realidade". ${ }^{1}$

Praz-me apresentar o conjunto de traduções aqui propostas por motivos vários. Em primeiro lugar, ele dá voz a personagens trágicas femininas e deixa falar representações potentes de mulheres antigas que, curiosamente, demonstram a permanência de questões pujantes ainda hoje. Em segundo lugar, agrada-me ver formar-se um Coletivo de Tradução que, de forma colaborativa e seguindo a metodologia da Trupe de Tradução de Teatro Antigo (Trüersa), produz, sob a regência de um diretor de tradução, textos vertidos de forma crítica e funcional. Eis um indício de que as práticas tradutórias desenvolvidas no Grupo de Tradução de Tea tro (GTT/CNPq) estão começando a dar frutos.

A Trüersa se propõe o desafio de colocar em discussão desde as palavras que trarão o texto ao português a té a encenação, a partir da interlocução permanente e coletiva com múltiplos questionamentos de diferentes campos do saber. Ta mbém os tradutores enfeixados neste projeto procuraram trilhar caminho semelhante.

Adotando o procedimento regular de discutir a tradução teatral como uma maneira de fazer - ou refazer - um texto, pensaram-no esteticamente comprometido com a prosódia do gênero, aquela que busca marcar ritmicamente, na linguagem, a força física da oralidade, nos moldes em que a propõe Henri Meschonnic ${ }^{2}$ e com a urgência dramatúrgica recomendada por Patrice Pavis. ${ }^{3}$

Sob essas diretrizes, os autores/tradutores/dramaturgistas encontraram-se para discutir os textos aqui reunidos. Cada texto ganhou um diretor de tradução responsável por estabelecer e harmonizar escolhas sintáticas, lexicais e estilísticas conforme suas próprias tendências.
2. MESCHONNIC. Linguagem, ritmo e vida.

3. PAVIS. "Para uma especificidade da tradução teatral". 
Nessa permuta, ainda que um pendesse para o estudo filológico, outro para a exequibilidade cênica, outro ainda para um viés mais poético e arcaizante, todos selaram um pacto de respeito e amizade para com o autor traduzido, o que, como se pode ver, gerou boas cenas, todas prontas para o palco.

Tereza Virgínia Ribeiro Barbosa UFMG/CNPq/Fapemig 


\section{ANDRÔMACA IN}

\section{AS TROIANAS, DE EURÍPIDES (V. 634 - 683)}

CONTEXTUALIZAÇÃO

A guerra entre gregos e troia nos é finda. Derrotados, os varões troia nos sucumbiram, mas... qual será o destino de suas mulheres? Sem esperança de verem seus maridos retornarem para o lar, elas sabem que agora são apenas presas de guerra. Se torna rão escravas? Servirão como esposas ou como amantes?

Eurípides, na peça As Troianas, colocou em cena pela primeira vez em 415 a.C. o drama e o impasse vivido por essas mulheres. Uma das personagens principais é Andrômaca, viúva de Heitor, a qual está destinada ao filho de Aquiles, Neoptólemo, algoz de seu marido. Fadada ao matrimônio, como ela reagirá diante da informação de que terá um novo marido? As núpcias podem ser arma de vingança ou alimento do luto? 


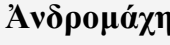

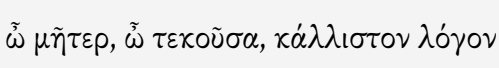

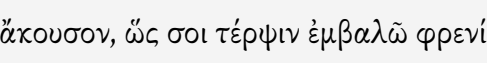

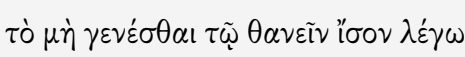

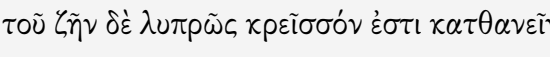

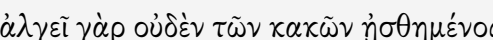

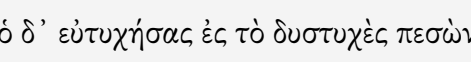

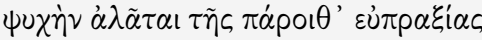

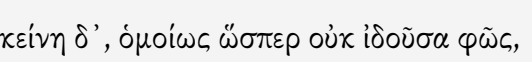

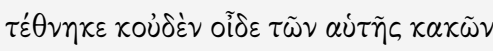

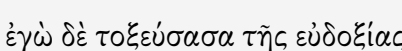

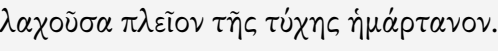

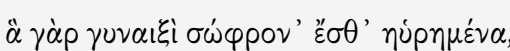

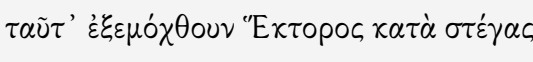

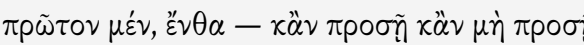

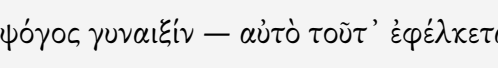

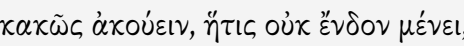

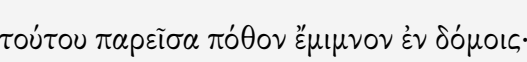

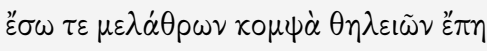

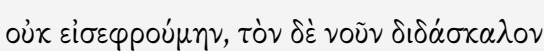

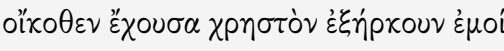

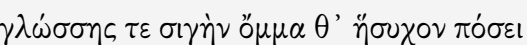

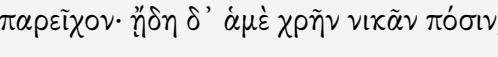

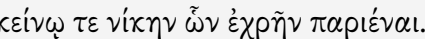

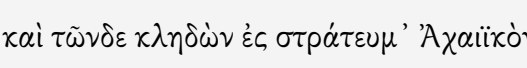

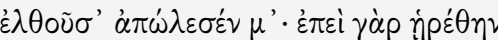

\section{ANDROMACA}

Ó mãe, ó geradora, escuta uma bela história,

a qual dará algum deleite ao teu peito.

Para mim, digo que nascer e morrer dá no mesmo,

mas viver infeliz é pior que morrer,

pois não sente a tristeza e a dor:

o afortunado que cai para a má sorte

a alma vagueia para o aconchego de antes..

Mas aquela, [Polixena], foi como se não tivesse visto a luz,

e morreu sem saber dos seus próprios males

Mas eu, eu alcancei a boa reputação

e fracassei em obter boa sorte.

Quanta castidade encontram para uma mulher,

a qual eu pelejei para alcançar sob o teto de Heitor...

E pra comecar - se tem ou se não tem um

defeito para a mulher - se ela não fica em casa

isso já é motivo para males ouvir,

e, tendo cedido a este desejo eu ficava em casa:

Para dentro das paredes palavras femininas sutis

não penetravam, mas me bastava ter um bom guia no peito:

a razão, me bastava para minha própria virtude.

Eu oferecia ao meu marido uns olhos calmos e uma língua silenciosa e eu

sabia qual vitória precisava ter sobre meu marido

qual vitória eu deveria ceder à ele.

E foi esta [minha] fama que, ao chegar no acampamento dos Aqueus 


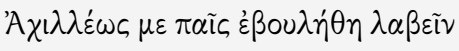

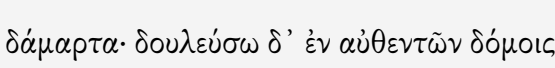

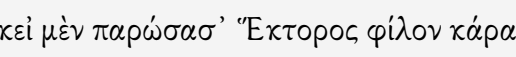

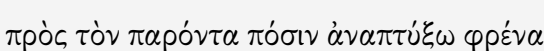

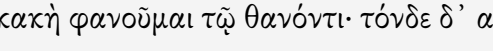

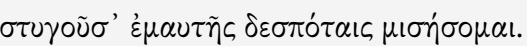

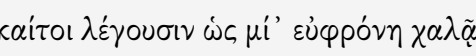

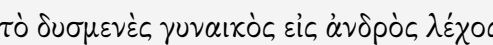

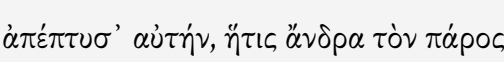

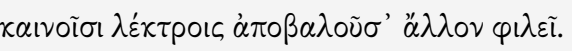

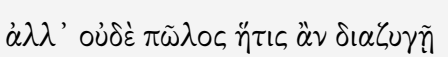

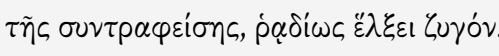

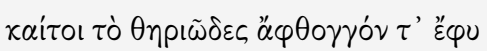

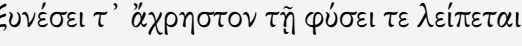

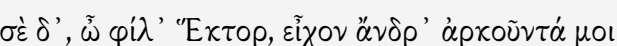

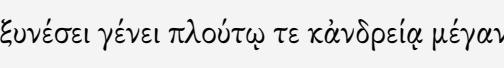

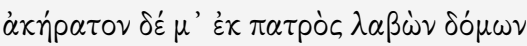

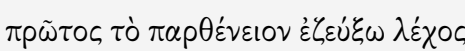

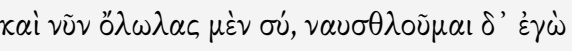

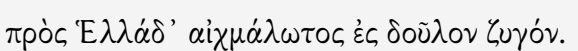

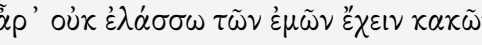

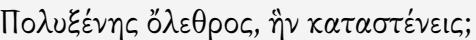

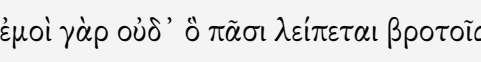

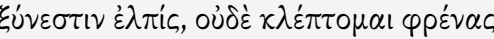

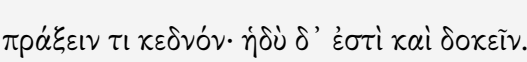

me destruiu: depois que fui tomada,

o moleque de Aquiles quis me pegar

para esposa: vou, então, servir no palácio de assassinos.

E se, deveras, da face amada de Heitor me esqueço

e pro marido seguinte eu abro o peito,

uma vadia pareço para o morto; e ao outro, que

eu mesma rejeito, então me faço odiada.

Sabe, dizem que uma noite de prazer relaxa

o leito da mulher hostil para o macho.

Escarro nela - na que rejeita o marido de antes

por um outro que ama em lençóis novos.

Mas nem mesmo égua que quebrasse o jugo

de parceira, facilmente se liberta.

Seja como for, o selvagem que nasce mudo

abandona a inteligência e sua natureza é inferior.

E tu, ah amado Heitor, eras meu homem - me satisfazias

no jugo, na ascendência, na riqueza, na grande virilidade,

e desde que fui levada donzela da casa de meu pai

o primeiro que trepou na cama solteira.

Agora que tu já estás morto, eu navego

para cativeiro grego, para um jugo servil.

Ora, não será a perda de Polixena

menor que meus males, que lamentas?

Pois a mim nem mesmo resta a esperança

que acompanha todos os mortais, nem me ilude que

haverá alguma alegria: mas é a meno imaginar. 


\section{ANTÍGONA IN: ANTÍGONA DE SÓFOCLES (V. 891-928)}

CONTEXTUALIZAÇÃO

Antígona de Sóflocles, quarto episódio (v. 891-928). Antígona, filha de Édipo e Jocasta, é acusada de agir contra a lei ao tentar realizar os ritos fúnebres de seus fratricidas irmãos Polinices e Etéocles. O episódio é um longo la mento da protagonista a respeito do terrível destino da família e da perda da parte comum da vida de uma mulher de então (casamento, filhos) por ter descumprido a lei. Ao mesmo tempo, Antígona demonstra uma desconcertante confiança em suas decisões, afirma ndo que o seu agir, apesar de ilegal,

foi correto. 


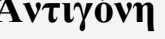

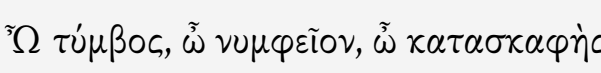

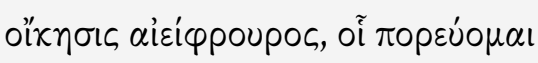

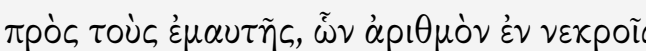

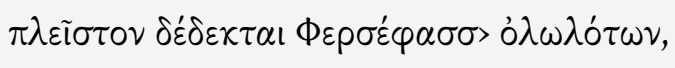

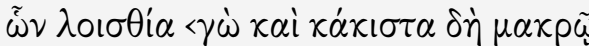

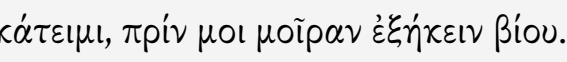

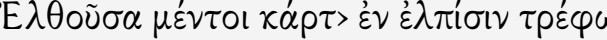

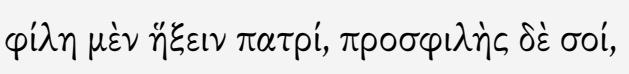

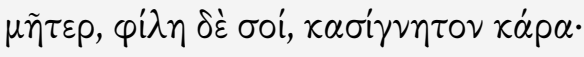

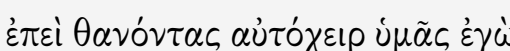

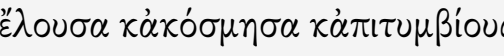

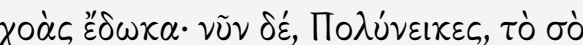

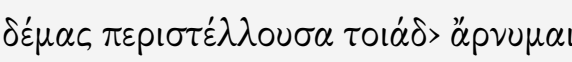

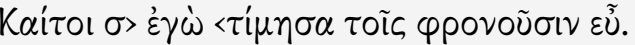

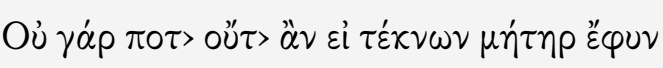

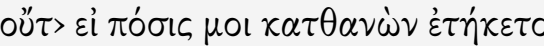

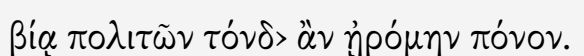

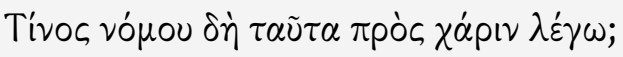

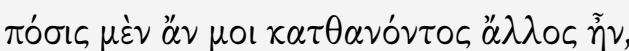

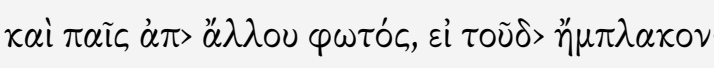

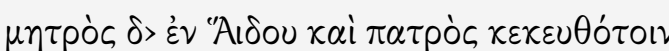

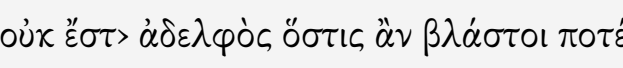

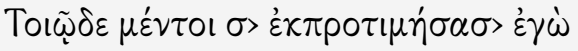

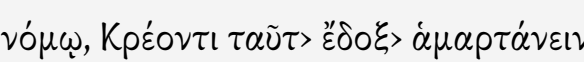

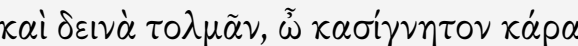

\section{ANTÍGONA}

Ó tumba, ó câmara nupcial, ó escavado

lar sempre vigilante a que me dirijo

em direç̃o aos meus, dos quais dentre os mortos

perecidos a maior parte Perséfone recebeu,

e dos quais a última, eu, certamente e por muito a pior, agora desço antes que meu quinhão de vida se encerre. Ao partir, sim, nutro tanto a esperança

de que serei amada pelo pai, querida por ti, mãe, amada por ti, rosto de meu irmão:

quando morrestes, de própria mão eu vos banhei e adornei, e sobre o túmulo

derra mei libações. E agora, Poliníces,

por ter coberto teus contornos isso recebo.

E eu tão bem te honrei aos olhos dos sábios...

Pois nem se me tornasse mãe de crianças,

nem se meu marido morto estivesse em decomposição

encetaria esses trabalhos contra a força da cidade.

Mas graças a que costume digo essas coisas?

Se o marido morresse, para mim outro haveria,

e também um filho de outro homem, se tivesse perdido um.

Mas com mãe e pai ocultos no Hades

não haveria nunca um irmão que rebentasse.

Por isso, é certo, eu te honrei acima de tudo,

por esse costume, e para Creonte pareci assim cometer um erro 


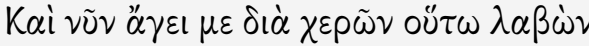

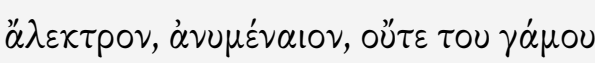

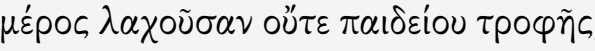
$\dot{\alpha} \lambda \lambda^{\prime} \tilde{\omega} \delta^{\prime}$ '̌̋

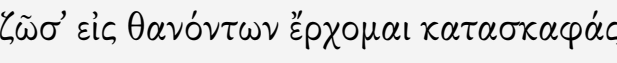

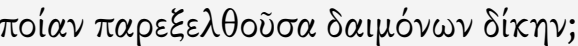

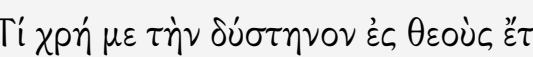

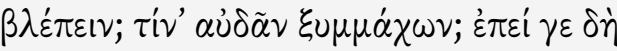

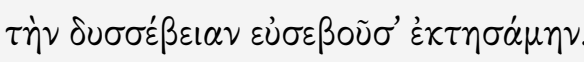

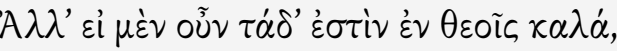

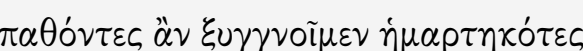

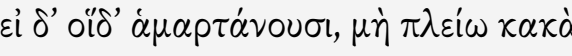

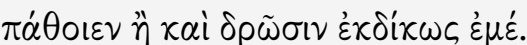

e ser fatalmente ousada, ó rosto de meu irmão

E agora ele me conduz assim pelas mãos, me deixa sem tála mo, sem himeneu, sem ter tido a sorte

de um casamento ou de criar uma crianç

e assim, desolada de amigos, a malfadada,

parto viva para as covas dos que já morreram,

por ter transgredido qual ordem divina?

Por que devo eu, a desgraçada, para os deuses ainda

olhar? Quais aliados devo invocar, já que

consegui me tornar a ímpia por ser piedosa?

Se tudo isso está certo para os deuses,

reconheceremos que erramos ao sofrermos.

Mas se eles erraram, que não sofram males maiores

dos que os que injustamente me fizeram passar. 


\section{FEDRA IN: HIPÓLITO DE EURÍPIDES (V. 373-430)}

CONTEXTUALIZAÇÃO:

Desejosa de punir o orgulhoso Hipólito, que se devotava apenas a Ártemis, a deusa Afrodite decide valer-se do seguinte estratagema para executar sua vingança: faria a madrasta de Hipólito, Fedra (casada com seu pai, Teseu), apaixonar-se por ele num incestuoso desejo proibido. Apesar de inocente, a mulher cai vítima do poder de Afrodite e, a princípio, tenta resistir em silêncio ao secreto mal. Com o tempo, contudo, diante da insistência de sua Nutriz, Fedra se expressa para ela e para o coro das mulheres de Trezena com as seguintes palavras... 


\section{ФAILPA}

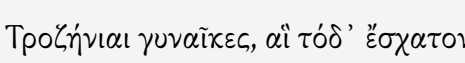

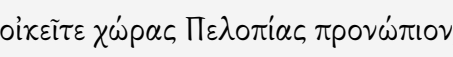

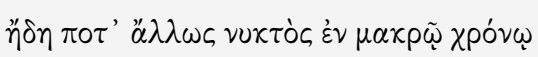

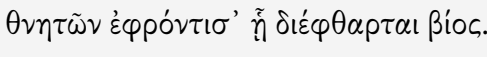

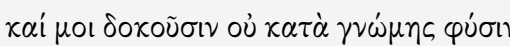

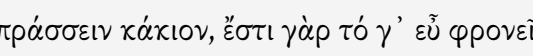

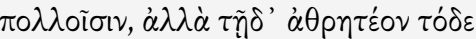

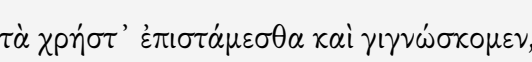

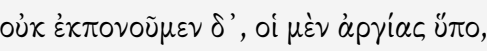

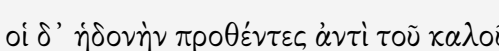

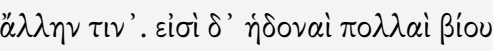

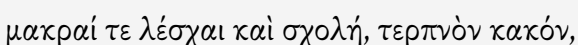

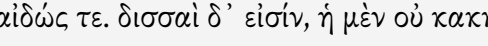

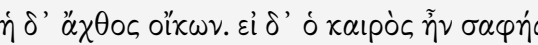

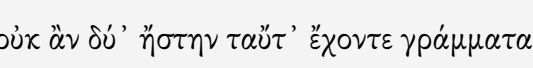

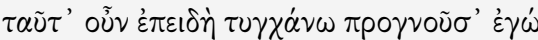

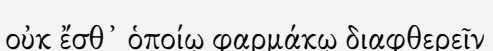

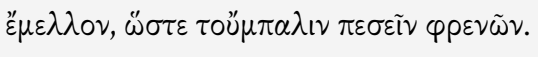

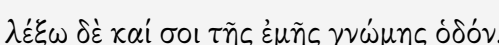

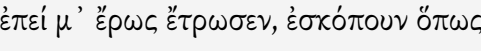

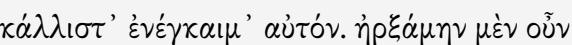

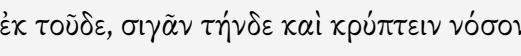

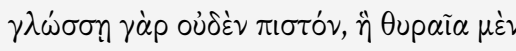

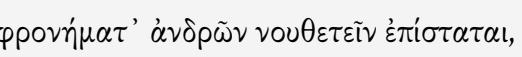

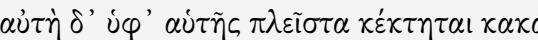

\section{FEDRA}

Mulheres de Trezena, que nesta extrema antessala da terra de Pélops morai,

em todo caso, longo tempo já à noite pensei em como, dos mortais, se arruína a vida.

A mim parecem não no fio do saber

fazerem mal, já que com isto têm bom senso muitíssimos, mas é preciso ponderar:

coisas úteis sabemos e compreendemos, mas não realiza mos - uns só por preguiça, outros por colocar antes do bem algum prazer. E são demais os prazeres desta vida

conversas longas e lazer - ah... doce mal e pudor. E, porém, são dois: um não é mau,

o outro, um fardo aos de casa... Fosse a coisa clara, ja mais teria dois com idênticas letras.

Já que calhei de concluir assim eu mesma não há droga nenhuma capaz de se opor a mim, a ponto de me revirar o fundo.

Direi a ti a senda desse meu saber: quando Eros me feriu, sondei o melhor modo para me opor a ele. Comecei então

por isto: silenciar e esconder essa mazela.

Pois nada certo vem da língua: porta afora,

a cabeça dos homens ela sabe instar 


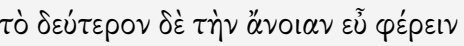

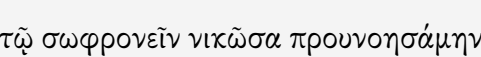

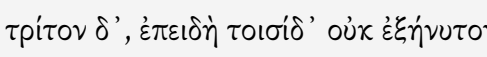

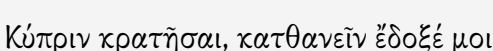

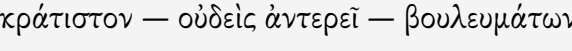

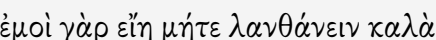

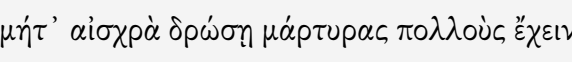

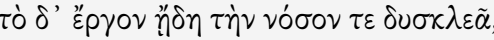

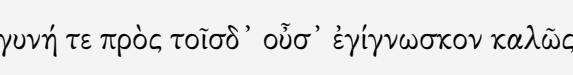

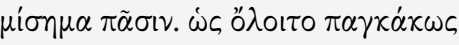

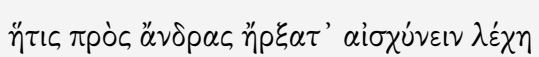

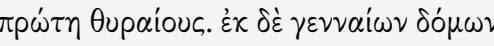

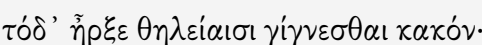

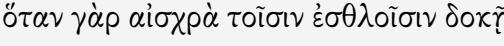

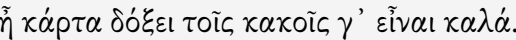

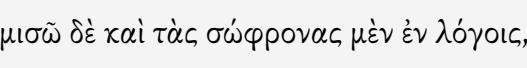

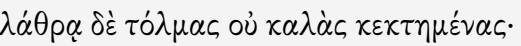

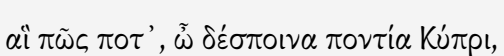

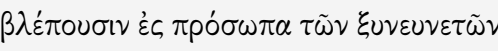

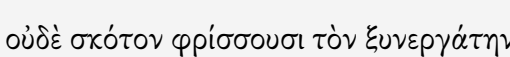

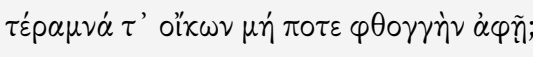

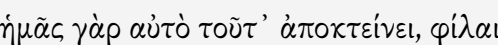

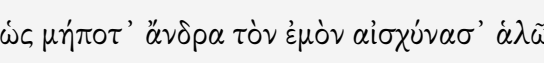

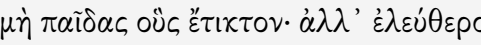

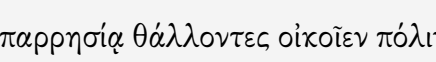

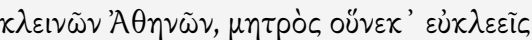

mas por si própria está cumulada de males. Segundo, para aguentar bem a insensatez, inventei de vencê-la em minha lucidez.

Terceiro, como com aquilo não cumpri vencer a Cípria, a mim pareceu que morrer seria o mais viril - ninguém nega - dos planos... Tal como não convém esquecer-se dos bens, não convém que as baixezas tenham testemunhas.

Conhecia meu ato e inglória mazela

e, além disso, sabia bem que era mulher,

a desgraça de todos... Que morra a maldita

responsável por arruinar, primeira, a cama

com homens porta afora. Das nobres famílias isso veio a ser para as mulheres um mal: se baixarias entre os melhores se veem,

elas parecerão aos maus ainda mais belas.

Odeio as que são castas da boca pra fora

e mantêm em segredo não belas audácias...

Como é possível, ó senhora do mar - Cípris -

que elas olhem de novo nos olhos dos cônjuges? E não tremam que a treva, cúmplice na trama,

as paredes do quarto rompam o silêncio?

É que essas coisas todas me matam, a migas...

Que eu jamais seja pega manchando o meu homem,

nem as crianças que gerei: mas que, ao contrário,

morem, livres na fala, brotando na pólis 


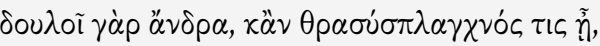

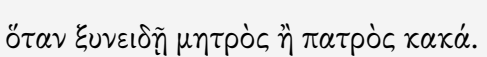

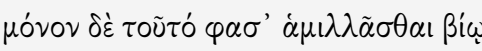

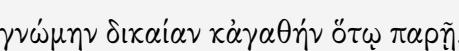

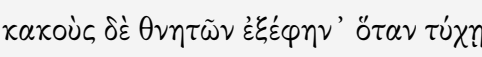

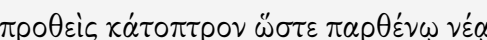

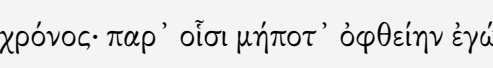

da ilustre Atenas - eles, ilustres na mãe.

Escraviza-se o homem, mesmo um destemido,

se alguém sabe de baixarias de um dos pais.

Só uma coisa, dizem, se equipara à vida:

apresentar a mente justa e soberana.

Dentre os mortais, os maus acabam descobertos -

como um espelho posto diante da donzela -

pelo tempo... Entre tais..., ja mais seja vista eu! 


\section{FEDRA IN: FEDRA DE RACINE (ATO I, CENA 3)}

CONTEXTUALIZAÇÃO

Fedra, cujo marido, Teseu, está desaparecido há mais de seis meses, sofre de um mal secreto que consome suas forças. Sua nutriz, Enone, preocupada, tenta convencê-la a falar sobre aquilo que a devora, a fim de que possam esclarecê-lo e encontrar algum tratamento. Fedra, a princípio, se recusa a falar sobre seu segredo proibido, mas a nutriz acaba levando-a a pronunciar a seguinte confissão... 


\section{PHEDRE}

Mon mal vient de plus loin. À peine au fils d'Égée Sous les lois de l'hymen je m'étais engagée,

Mon repos, mon bonheur semblait être affermi ; Athènes me montra mon superbe ennemi :

Je le vis, je rougis, je pâlis à sa vue ;

Un trouble s'éleva dans mon âme éperdue ;

Mes yeux ne voyaient plus, je ne pouvais parler

Je sentis tout mon corps et transir et brûler :

Je reconnus Vénus et ses feux redoutables,

D'un sang qu'elle poursuit tourments inévitables

Par des voux assidus je crus les détourner:

Je lui bâtis un temple, et pris soin de l'orner

De victimes moi-même à toute heure entourée,

Je cherchais dans leurs flancs ma raison éga rée :

D'un incurable amour remèdes impuissants!

En vain sur les autels ma main brûlait l'encens !

Quand ma bouche implorait le nom de la déesse,

J'adorais Hippolyte ; et, le voyant sans cesse,

Même au pied des autels que je faisais fumer,

J'offrais tout à ce dieu que je n'osais nommer.

Je l'évitais partout. Ô comble de misère!

Mes yeux le retrouvaient dans les traits de son père.

Contre moi-même enfin j'osai me révolter :

J'excitai mon courage à le persécuter.

Pour bannir l'ennemi dont j'étais idolâtre,

\section{FEDRA}

Meu mal vem de mais longe... Se ao filho de Egeu

Com pouco me obrigava - nas leis do himeneu -,

Meu repouso..., meu gosto parecia assente...

E Atenas me mostrou meu soberbo oponente:

Eu o vi, rubesci, esvaeci sob a vista...

Um tumulto elevou-se em minha alma contrista.

Meus olhos não mais viam e eu..., nada a dizer.

Senti meu corpo todo congelar e arder:

Reconheci os fogos - e Vênus - mutáveis,

De um sangue que ela acossa..., os males implacáveis.

Acreditei com votos assíduos desviá-los:

Fundei-lhe um templo..., ofereci alguns regalos...

De vítimas eu mesma há pouco envolvida,

Em seus flancos buscava a razão seduzida:

Para amor incurável..., remédios sem senso!

Em vão - no altar - queimava minha mão o incenso!

Se minha boca instava o nome de tal diva,

Eu adorava Hipólito... E, ao ver-me cativa

Mesmo diante do altar que eu fazia abrasar

Oferecia tudo ao deus..., sem o nomear.

Eu o evitava em tudo. Ó cúmulo dos ais!

Meus olhos o encontravam nos traços do pai.

Contra mim mesma, enfim, provoquei certo abalo

E estimulei meu ânimo a fim de rechaçá-lo... 
J'affectai les chagrins d'une injuste marâtre ;

Je pressai son exil ; et mes cris éternels

L'arrachèrent du sein et des bras paternels.

Je respirais, Enone ; et, depuis son absence,

Mes jours moins agités coulaient dans l'innocence :

Soumise à mon époux, et cachant mes ennuis,

De son fatal hymen je cultivais les fruits.

Vaines précautions! Cruelle destinée !

Par mon époux lui-même à Trézène amenée,

J'ai revu l'ennemi que j'avais éloigné :

Ma blessure trop vive aussitôt a saigné.

Ce n'est plus une ardeur dans mes veines cachée

C'est Vénus tout entière à sa proie attachée.

Jai conçu pour mon crime une juste terreur ;

J'ai pris la vie en haine, et ma flamme en horreur

Je voulais en mourant prendre soin de ma gloire,

Et dérober au jour une flamme si noire:

Je n'ai pu soutenir tes larmes, tes combats ;

Je t'ai tout avoué ; je ne m'en repens pas.

Pourvu que, de ma mort respectant les approches,

Tu ne m'affliges plus par d'injustes reproches,

Et que tes vains secours cessent de rappeler

Un reste de chaleur tout prêt à s'exhaler.
Por banir o rival de quem era entusiasta, Eu fingia a repulsa de injusta madrasta..

Cla mava seu exílio... E meus gritos eternos

Tiraram-lhe do seio e dos braços paternos.

Eu respirava, Enone... E, desde sua ausência,

Meus dias menos turvos vinham na inocência.

Submissa a meu marido, e escondendo meu luto,

Do fatal himeneu eu cultivava o fruto.

Vãs..., vãs precauções! Ó cruenta desdita! Pelo esposo em pessoa a Trezena volvida,

Vi de novo o rival que eu havia afastado.

Logo sangrou o ferimento mal curado.

Já não é uma ardência nas veias calada.

É Vênus toda inteira à sua presa agarrada.

Concebi por meu crime o mais justo terror:

Tomei em ódio a vida..., meu fogo em horror..

Gostaria, morrendo, de manter meu brio,

E arrebatar, à luz, este fogo sombrio...

Não pude suportar teu choro..., teu assalto...,

A ti, tudo admiti... Não mais me sobressalto.

Contudo, respeitando o fim de minha vida,

Já não me aflijas mais com censura indevida

E que teus vãos chamados cessem de evocar

Um resto de calor..., a ponto de expirar. 


\section{HELENA IN: HELENA DE EURÍPIDES (V. 255-305)}

CONTEXTUALIZAÇÃO

Helena de Eurípides narra a saga da mulher mais bonita do mundo, que teria sido levada para Troia por Paris Alexandre, um dos filhos de Pría mo, rei de Troia. Em algumas versões, Paris e Helena teriam se apaixonado, e ela teria fugido com ele para Ílion, abandonando seu marido, Menelau, e sua filha em Esparta. Em outras versões, ela foi raptada por ele. De todo modo, essa lenda continua o mito de Helena, filha de Zeus e Leda, e a mulher mais bela que o mundo já conheceu. Ela foi prometida a Paris por Afrodite, na questão do pomo de ouro. $\mathrm{O}$ pomo foi o motivo da discórdia entre três deusas: Atena, Afrodite e Hera, que disputavam entre si o título de mais bela. No casamento de Tétis e Peleu, pais de Aquiles, Éris, a deusa da discórdia, não foi convidada, e como vingança fez uma aparição triunfa em meio às celebrações e deixou o pomo dizendo: "para a deusa mais bela”. Paris, que até então era um simples pastor (ele havia sido abandonado por seus pais, que queriam matá-lo por causa de uma profecia de que ele seria a ruína de Ílion, mas o camponês para quem ele foi entregue não teve coragem para matá-lo e o criou como seu filho. Suas origens reais fora $\mathrm{m}$ reveladas mais tarde e ele voltou para o palácio de seus pais), foi escolhido como juiz do a rgumento. Cada deusa lhe prometeu presentes esplêndidos, mas ele escolheu Afrodite, que lhe prometera a mulher mais bela do mundo.

A tragédia foi escrita por Eurípides para redimir a "adúltera" Helena. Nela, o espectador fica sabendo que Paris levou uma cópia de Helena, feita do mesmo material das nuvens, enquanto a verdadeira Helena estava no Egito, sob a proteção do rei Proteu. Quando a tragédia começa, o rei está morto, e seu filho assume o poder. Helena está para ser obrigada a se casar com o novo sobera no, que não pretende honrar a promessa do pai de proteger a rainha de Esparta e guardá-la para quando Menelau voltasse. Num momento de desespero, Helena profere o seguinte discurso: 


\section{EA'HNH}

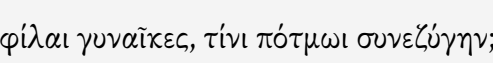

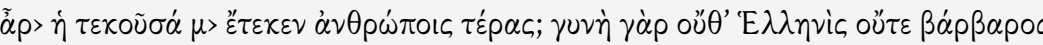

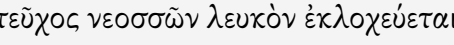

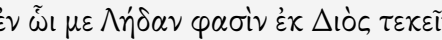

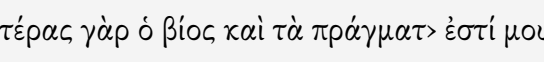

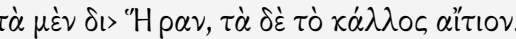

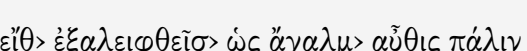

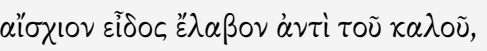

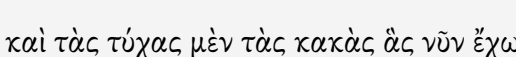

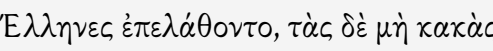

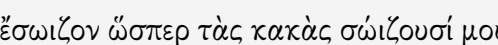

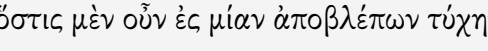

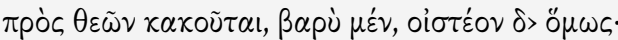

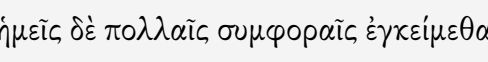

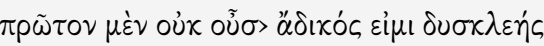

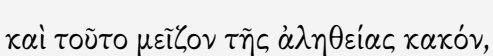

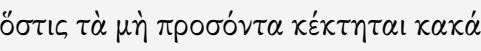

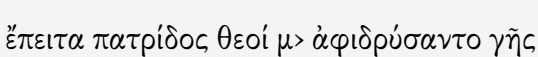

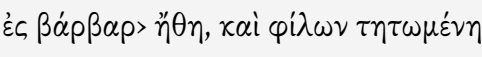

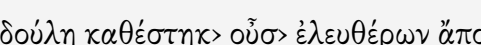

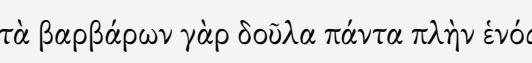

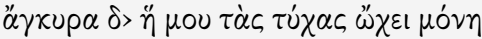

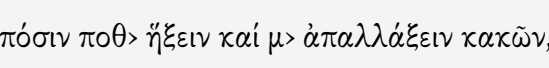

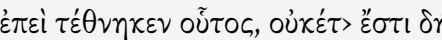

\section{HELENA}

Mulheres queridas, a qual sina estou atrelada?

Então a mãe me gerou para humanos como assombro? pois mulher, nem grega

[nem bárbara,

um recipiente branco de passarinhos ja mais pariu,

como o no qual dizem Leda de Zeus ter me gerado

Assombro pois a vida e as coisas minhas são,

as que em Hera e na beleza têm a causa.

Se, destruída como estátua, ou ainda

feia forma tomasse, oposta à bela,

então a sina e os males que agora tenho

os helenos esqueceriam, e os não-males

guardariam, como agora guardam meus males.

Qualquer um que, mirando um só destino,

pelos deuses maltratado, é pesado, mas ainda suportável;

nós, contudo, por muitas misérias esta mos circundadas.

Primeiro, e não sendo injusta, estou desonrada,

e maior do que a verdade é este mal:

alguém ter adquirido males que não lhe pertencem.

Depois da pátria os deuses me removeram da terra

aos bárbaros assentamentos, dos amigos privada,

escrava tornada, mesmo sendo livre de origem,

pois entre bárbaros, todos são escravos, exceto um.

a âncora que minha sina fixava, a única.

o esposo que um dia viria para me livrar dos males..

esse...está morto...esse...não é...mesmo....mais. 


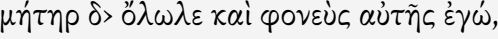

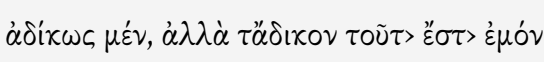

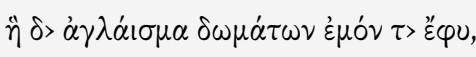

Өvүáan

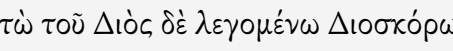

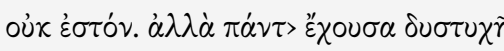

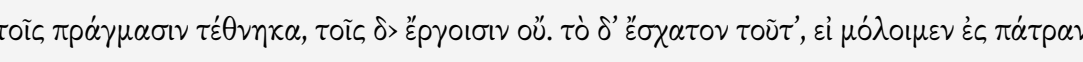

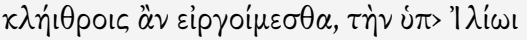

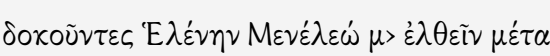

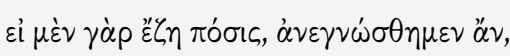

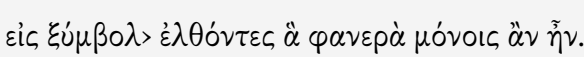

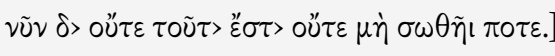

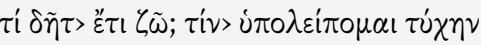

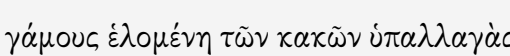

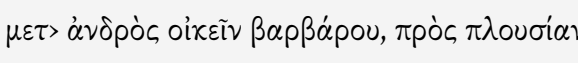

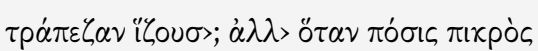

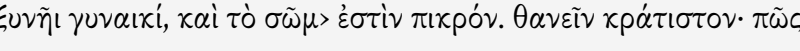

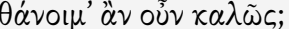

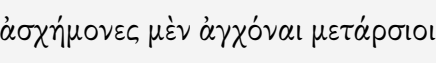

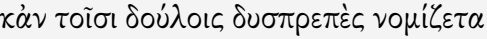

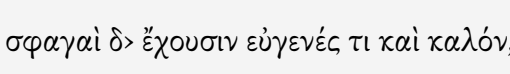

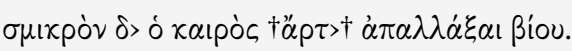

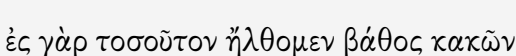

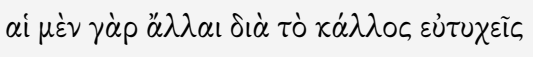

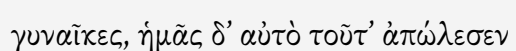

A mãe, finada...e a assassina dela? Eu!

Injusto, mas esse injusto é meu.

Ela então, orna mento das casas por mim produzido,

filha...sem marido...cinzenta...segue virgem...

Os filhos de Zeus, chamados Dióscuros,

não são. Mas em tudo sempre sou azarada,

para as benesses estou morta, para os sofrimentos, não

E o pior é isso: se eu pudesse voltar para a pátria

pelos ferrolhos seria barrada, pensando em mim

como a Helena que foi com Menelau para Ílio.

Pois, se vivesse o esposo, nós nos reconheceríamos,

retornando aos sinais visíveis apenas a nós.

Mas agora nem isso, nem salvo estaria algum dia.

Por que então ainda vivo? Que sina me resta?

Ser presa num casamento em troca dos males,

com um homem bárbaro viver, numa farta

mesa assentada? Mas quando um esposo é a margo,

para uma mulher comum, também o corpo fica amargo.

Morrer é o melhor: como então eu poderia morrer com nobreza?

Vergonhosos são os enforcados suspensos,

até aos escravos é considerado indigno.

Com punhal, que os bem-nascidos portam, é nobre

mas é curto o momento exato pra se desprender da vida.

Assim pois, viemos ao fundo dos males,

já que as outras pela beleza são beneficiadas,

mulheres, mas a nós...a mesma coisa destruiu. 


\section{JOCASTA IN: AS FENÍCIAS DE EURÍPIDES (528-585)}

CONTEXTUALIZAÇÃO

A história da família de Édipo contada na visão de Eurípides. Condensando as três tragédias de Ésquilo em uma só, Eurípides conta a saga da família de Laio, com seu filho Édipo que o mata e se casa com sua mulher, a mãe dele. Jocasta e Édipo têm quatro filhos: Etéocles, Polinices, Ismene e Antígona. Édipo acaba por descobrir toda a sua história e amaldiçoa sua família: dizendo que ele próprio devia ser exilado e seus filhos se matariam na frente do palácio. Etéocles convence Polinices a sair de Tebas por um ano, e voltar e então eles se revezariam no trono. Mas quando ele volta, Etéocles não abre mão do poder e exila o irmão, que se alia ao rei de Argos e volta para reaver seu direito ao trono. Etéocles e Polinices se matam, sua mãe/ avó se mata ao saber que a mbos estava m mortos, e o irmão dela, Creonte, exila Édipo, proíbe o enterro de Polinices, e obriga Antígona a se casar com seu próprio filho, Hêmon. No final da tragédia Antígona e Édipo partem para o exílio e a família de Creonte assume o comando de Tebas. Nesse monólogo, Jocasta, num último momento de desespero, fala aos dois filhos, esperando convencê-los a não se matarem pelo trono: 


\section{IOKA $\Sigma T H$}

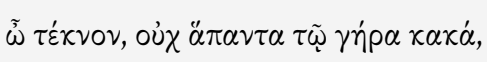

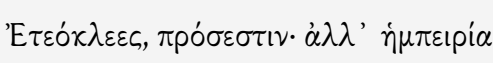

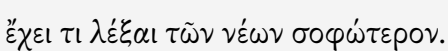

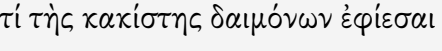

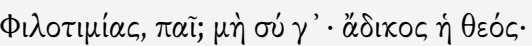

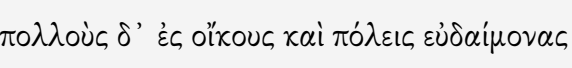

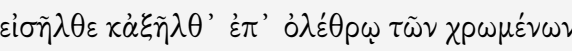

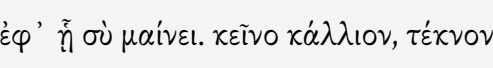

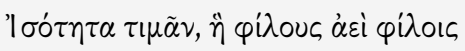

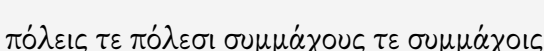

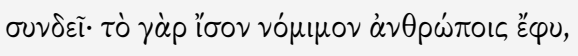

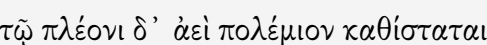

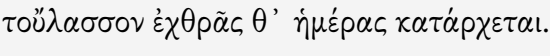

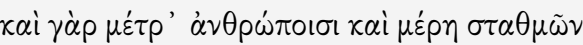

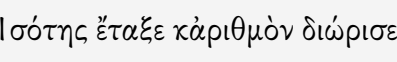

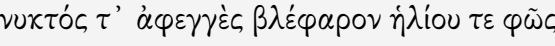

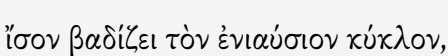

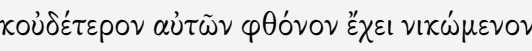

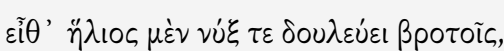

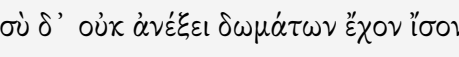

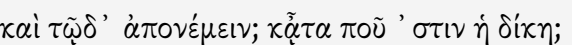

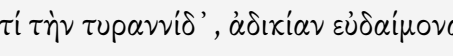

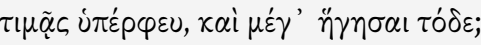

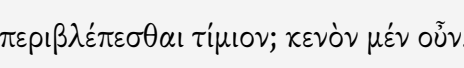

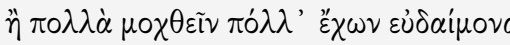

\section{JOCASTA}

Ô cria, vem cá! Nem tudo é ruim

na velhice, Etéocles: a experiência

assegura falar aos novos com mais sabedoria.

Criança, porquê cobiças a Ambição,

o pior dos espíritos? Não o faças! Injusta é a deusa!

Em muitas casas e cidades felizes

entrou, e saiu deixando a ruína para seus servos;

enlouqueces por ela! Ó cria, mais belo

é honrar à Igualdade, a qual une amigos a amigos,

cidades a cidades e aliados a aliados;

pois normalmente essas coisas a igualdade produz.

Já para o maior, o menor é sempre um

inimigo, e assim começam as lutas diárias.

A Igualdade estabeleceu a medida e os pesos

para os homens, e os números dividiu:

a pálpebra escura da noite e a luz do sol

caminham, como iguais, no correr do ano,

e um não guarda inveja do outro quando vencido.

Se o sol e a noite servem aos mortais,

Por que tu não cedes e aceitas dividi

casa? Onde está a justiça nesse seu comportamento?

Por que tanto honras à tirania, essa

injusta bem-aventurada, e a ela tens como grande comandante?

Para ser olhado com honra? Fútil, certamente! 


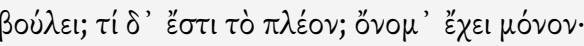

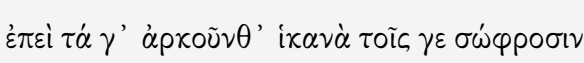

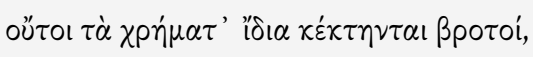

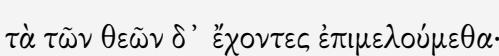

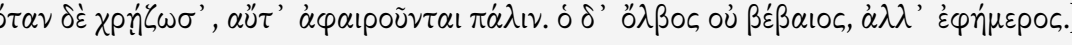

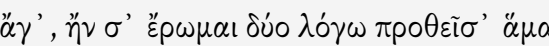

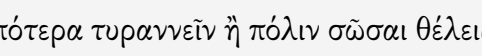

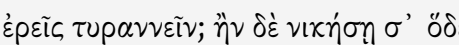

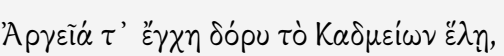

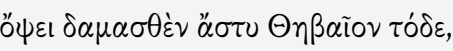

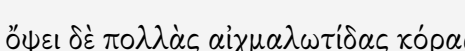

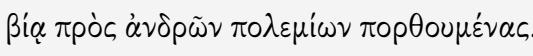

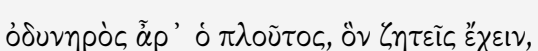

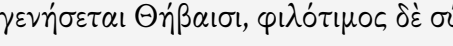

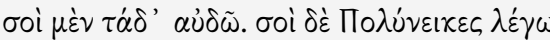

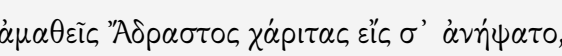

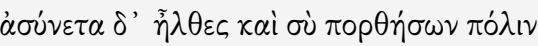

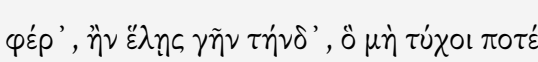

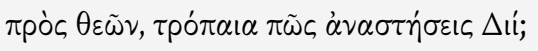

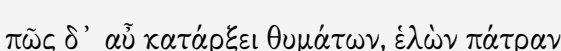

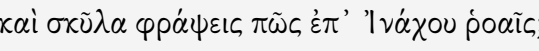

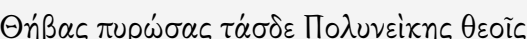

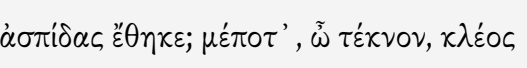

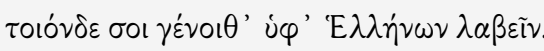

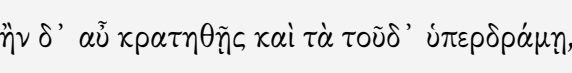

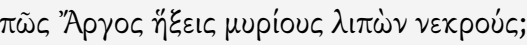

Ou desejas muito padecer, ao possuir muitos

bens? O que é a abundância? Persegues um nome somente!

Já os sábios contentam-se com o suficiente.

Os mortais, de fato, não são proprietários de seus bens, apenas guardam com cuidado isto que é dos deuses;

eles, quando querem, os tomam de volta.

A riqueza não é constante, mas efêmera.

Vamos! Se a ti duas sedutoras propostas fossem colocadas ao mesmo tempo

- tiranizar ou salvar a cidade - qual delas escolherias?

Tiranizar? Se o outro te vencer

e as armas argivas vencerem as lanças dos cadmeus,

verás a esta cidade de Tebas derrotada

verás muitas mulheres cativas,

sendo violentadas, a força, pelos homens inimigos.

Ganancioso! Dolorosa será para os tebanos

a riqueza que buscas ter.

Isto te digo! A Polinices, no entanto, falo:

Adrastos te amarrou a estúpidas graças

e como um tolo vieste para destruir a cidade.

Vejamos! Se, pelos deuses, tomares a esta terra

- que isso ja mais aconteça -, como erguerias monumentos a Zeus?

Como darias início aos sacrifícios por tomar a pátria?

E como inscreverias os espólios diante da fonte de Ínaco?

Polinices, ofertarias esses escudos aos deuses

enquanto Tebas queima? Ô cria! Que tu nunca

recebas essa glória por conquistar aos Helenos! 


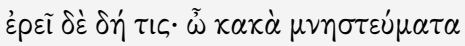

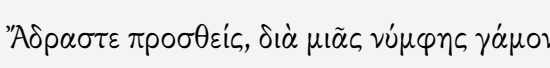

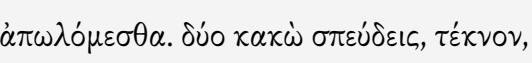

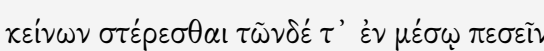

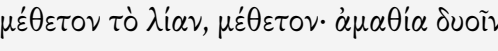

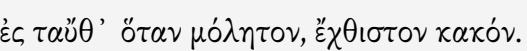

Porém, se fosses derrotado e ele prevalecesse,

como retornarias a Argos abandonando incontáveis corpos?

Alguém certamente perguntará: "Ó Adrasto, bodas

letais arranjaste: por causa do casamento de tua filha

fomos chacinados." Cria, buscas dois males:

ser privado daqueles e, no meio disto, morrer.

Deixai de excesso, deixai! A vossa estupidez,

quando se iguala, é a mais odienta praga. 


\section{JOCASTA IN: AS FENÍCIAS DE SÊNECA (V. 480-585)}

CONTEXTUALIZAÇÃO :

Guerra civil em Tebas: dois irmãos (Etéocles e Polinices) disputa m o trono deixado vago por Édipo, pai e, ao mesmo tempo, irmão da dupla. Jocasta, simultanea mente mãe e avó dos dois beligerantes, busca resgatar a concórdia fraterna ante o desastre iminente. Em um acordo anterior, os dois irmãos revezariam o trono, cada um reina ndo pelo período de um ano. Ao fim do governo de Etéocles, porém, Polinices foi exilado. Retorna tempos depois, casado com a filha do rei de Argos e à frente de um exército estrangeiro reivindicando sua vez de reinar.

A cena se passa em pleno campo de batalha, Jocasta se posicionando entre os dois filhos-netos. Momentos antes, ela pedira a Polinices que embainhasse sua espada, retirasse o elmo, depusesse a lança e o escudo que a impediam de abraça-lo. Prometendo garantir a sua segurança, oferece seu próprio corpo como barreira a um eventual a taque do outro irmão. Polinices, entretanto, rejeita a oferta materna dizendo que em nada poderia confiar, nem mesmo em sua mãe, pois “já nada valem as leis da natureza”. Jocasta então responde: 


\section{IOCASTA}

Redde iam capulo manum

astringe galeam, laeva se clipeo inserat; dum frater exarmatur, armatus mane.

tu pone ferrum, causa qui ferri es prior. si pacis odium est, furere si bello placet: indutias te mater exiguas rogat,

ferat ut reverso post fugam nato oscula

vel prima vel suprema, dum pacem peto, audite inermes, ille te, tu illum times?

ego utrumque, sed pro utroque, quid strictum abnuis

recondere ensem? qualibet gaude mora:

id gerere bellum cupitis, in quo est optimum

vinci, vereris fratris infesti dolos?

quotiens necesse est fallere aut falli a suis,

patiare potius ipse quam facias scelus.

sed ne verere: mater insidias et hinc

et rursus illinc abiget. exoro? an patri

invideo vestro? veni ut arcerem nefas

an ut viderem propius? hic ferrum abdidit,

reclinis hasta est, arma defixa incubant.

ad te preces nunc, nate, maternas feram,

sed ante lacrimas, teneo longo tempore

\section{JOCASTA}

Restitui, então, a mão ao punho da espada,

Prende o elmo, que a mão esquerda carregue o escudo!

Enquanto teu irmão está desarmado, armado persiste.

Afasta o ferro, tu que és a causa primeira deste ferro.

Se tens ódio da paz, se te apraz enfurecer-te na guerra,

tua mãe te roga uma pequena trégua,

a fim de que ela receba os beijos, os primeiros ou os últimos,

do filho que voltou do exílio. Enquanto peço pela paz,

ouvi sem armas. Tens medo dele e ele de ti?

Eu mesma temo por ambos, mas também a favor de ambos.

Por que te negas a guardar a espada? Alegra-te com esta pausa:

Desejas fazer uma guerra na qual o melhor

é ser vencido! Receias as trapaças de um irmão hostil

Entre enganar e ser enga nado pelos seus,

melhor é suportar a má ação do que cometê-la

Mas não temas: a mãe impedirá armadilhas

tanto daqui quanto de lá. Eu vos acalmo,

ou devo invejar vosso pai? Vim para evitar uma atrocidade,

ou para dela ser testemunha? Este (Etéocles) já afastou a espada

sua lança está reclinada e a arma permanece imóvel.

A ti (Polinices) levarei agora, ó filho, as preces maternas,

mas, antes, as lágrimas. Por muito tempo

tenho pedido aos deuses, com votos, o teu semblante.

A ti, exilado do solo pátrio e protegido pelos Penates de um rei estrangeiro. 
petita votis ora. te profugum solo

patrio penates regis externi tegunt.

te maria tot diversa, tot casus vagum

egere, non te duxit in thala mos parens

comitata primos nec sua festas manu

ornavit aedes nec sacra laetas faces

vitta revinxit; dona non auro graves

gazas socer, non arva, non urbes dedit:

dotale bellum est. hostium es factus gener,

patria remotus hospes alieni laris,

externa consecutus, expulsus tuis,

sine crimine exul. ne quid e fatis tibi

desset paternis, hoc quoque ex illis habes,

errasse thala mis, nate post multos mihi

remissa soles, nate suspensae metu

et spes parentis, cuius aspectum deos

semper rogavi, cum tuus reditus mihi

tantum esset erepturus, adventu tuo

quantum daturus: 'quando pro te desinam'

dixi 'timere?' dixit inridens deus

'ipsum timebis.' nempe nisi bellum foret,

ego te carerem; nempe si tu non fores,

bello carerem. Triste conspectus datur

pretium tui durumque, sed matri placet.

hinc modo recedant arma, dum nullum nefas

Mars saevus audet: hoc quoque est magnum nefas.
A ti, que tantos mares adversos e tantos acasos

impeliram errante. Uma mãe não te acompanhou às núpcias,

nem ornou a casa em festa com suas mão

nem amarrou as alegres tochas com fitas.

Teu sogro não te deu presentes, nem pesados tesouros em ouro

nem searas, nem cidades

Mas recebestes a guerra como dote, pois te tornastes genro do inimigo

afastado da pátria, hóspede de Lares alheios,

acompanhado por estrangeiros, expulso dos teus

exilado sem crime. Não faltas nada a ti,

pois, da desgraça paterna tens também isto:

um casamento enganoso. ó Filho, que após muitos sóis

retornou para mim; ó filho, medo e esperança

de uma mãe alarmada, cuja visão sempre roguei

aos deuses, mas cujo retorno irá arrebatar de mim

tudo quanto a tua chegada poderá dar:

"quando deixarei de temer por ti?"

perguntei, e um deus zombador respondeu

"temerás ele próprio". Sem dúvida, se a guerra não existisse

eu não te teria aqui; e, se tu não existisse

eu não teria a guerra. Um preço triste e duro é oferecido

pela tua presença; mas, mesmo assim, me agrada.

Que o teu exército se afaste daqui imediatamente,

enqua nto o cruel Marte não ousa nada nefasto. Mas isto é igualmente

[nefasto:

estarem ambos tão perto. Espantada, tremo pálid
EM TESE

BELO HORIZONTE

v. 24

N. 2

MAIO-AGO. 2018

UPLT. Vozes de mulheres da Antiguidade [...]

P. $173-211$

Tradução e Ediç̧ão 
tam prope fuisse, stupeo et exsanguis tremo, cum stare fratres hinc et hinc video duos sceleris sub ictu. membra quassantur metu: quam paene mater maius aspexi nefas. quam quod miser videre non potuit pater. licet timore facinoris tanti vacem

videamque iam nil tale, sum infelix tamen quod paene vidi. per decem mensum graves uteri labores perque pietatem inclitae precor sororis et per irati sibi

genas parentis, scelere quas nullo nocens, erroris a se dira supplicia exigens,

hausit: nefandas moenibus patriis faces averte, signa bellici retro agminis

flecte - ut recedas, magna pars sceleris tamen vestri peracta est: vidit hostili grege campos repleri patria, fulgentes procul armis catervas vidit, equitatu levi Cadmea frangi prata et excelsos rotis volitare proceres, igne flagrantes trabes fumare, cineri quae petunt nostras domos, fratresque (facinus quod novum et Thebis fuit)

in se ruentes: totus hoc exercitus,

hoc populus omnis, utraque hoc vidit soror genetrixque vidi: nam pater debet sibi ao ver dois irmãos, de um lado e de outro,

na iminência do crime. Todo meu corpo se agita de medo.

O quão próximo tua mãe está diante de uma coisa ainda mais nefasta

que aquela que o teu infeliz pai não pôde ver.

É lícito temer: ainda que tenha tempo

e que até agora não mire tal crime, no entanto, sou infeliz pois por pouco vi. Pelos nove meses de pesado

labores do meu útero, pela devoção de tua ilustre irmã,

e pelos olhos de teu pai, arrancados, em ódio de seu erro, culpando-se de um crime inexistente

e exigindo de si terríveis suplícios:

Eu te suplico: afaste as tochas nefastas das muralhas pátrias;

vá embora daqui com os estandartes deste belicoso exército! Pois, mesmo que recues agora, grande parte de vosso crime está realizada: a pátria viu os campos serem tomados pela multidão hostil, brilhando em armas ao longe; viu os prados Cádmos serem rasgados pela cavalaria veloz

e os notáveis chefes estrangeiros a correr daqui e dali em seus carros; os bosques, devastados pelas chamas,

a lançar fumaça e cinzas que atingem nossas casas;

e irmãos lançando-se um contra o outro, ofensa que ainda era desconhecida em

O exército inteiro isso viu, todo o povo, tuas duas irmãs,

tua criadora viram: de fato, teu pai tem sorte

de não mais ter olhos para tal! Que agora se

aproxime de ti Édipo, qual juiz, pois a expiação 
quod ista non spectavit, occurrat tibi nunc Oedipus, quo iudice erroris quoque poenae petuntur. ne, precor, ferro erue patriam ac penates neve, quas regere expetis, everte Thebas. quis tenet mentem furor? petendo patriam perdis? ut fiat tua,.

vis esse nullam? quin tuae causae noce ipsum hoc quod armis uris infestis solum segetesque adultas sternis et totos fugam edis per agros: nemo sic vastat sua; quae corripi igne. quae meti gladio iubes aliena credis, rex sit ex vobis uter,

manente regno quaerite, haec telis petis fla mmisque tecta? poteris has Amphionis quassare moles? nulla quas struxit manus stridente tardum machina ducens onus, sed convocatus vocis et citharae sono per se ipse summas venit in turres lapis: haec saxa franges? victor hinc spolia auferes vinctosque duces patris aequales tui, matresque $\mathrm{ab}$ ipso coniugum raptas sinu saevus catena miles imposita trahet? adulta virgo, mixta captivo gregi, Thebana nuribus munus Argolicis eat? an et ipsa, palmas vincta postergum datas, mater triumphi praeda fraterni vehar? do erro é igualmente reclamada.

Eu suplico: não destrua com o ferro a pátria e os

Penates; e não arruíne Tebas, na qual desejas reinar.

Que furor é este que conservas em tua alma?

Perderás a pátria reclamando-a? Desejas que,

tornando-a tua, ela seja aniquilada pela força?

Tudo isso prejudica a tua própria causa: cobres o solo

com um exército de homens hostis, derrubas a colheita madura

e provocas a fuga em nosso território! Ninguém devasta assim o que seu! Acaso desconheces tudo isto que reduzes ao fogo

e que repartis com a espada?

Decidi entre vós dois quem será rei, mas que reste algo a se reinar.

Atacas estas casas com chamas e dardos? Podereis abalar

estes edifícios de Anfião? Os quais nenhuma mão,

conduzindo a carga pesada, construiu com máquinas estridentes:

foram convocadas pelo som da lira e de sua voz;

e cada pedra se moveu, por conta própria, até as mais elevadas torres.

Quebrarás estes blocos de pedra? Vencedor, levarás daqui os despojos

e os chefes vencidos, tão ilustres quanto teu pai?

E as mães, arrebatadas dos braços de seus próprios maridos

um furioso soldado as arrastará, a marradas?

Caminhará a virgem tebana misturada à multidão de cativo

como presente para uma futura nora de Argos?

Serei eu própria levada, amarrada com as mãos nas costas,

como um prêmio do teu triunfo fraternal?

Serás capaz de ver teus súditos lançados, em desordem, à morte e ao exílio? 
potesne cives leto et exilio datos

videre passim? moenibus caris potes

hostem admovere, sanguine et flamma potes

implere Thebas? tam ferus durum geris

saevumque in iras pectus? et nondum imperas.

quid sceptra facient? pone vaesanos, precor,

animi tumores teque pietati refer.
És capaz de trazer o inimigo para perto de tuas queridas muralhas?

De encher Tebas com sangue e chamas?

Ainda nem governas, e tamanha é a ira que trazes nesse teu peito violento,

duro e cruel! E o que produzirá ela quando tiveres o cetro?

Afasta essa cólera louca do teu espírito, eu te suplico,

e torne a trazer nele o a mor à pátria e aos pais. 


\section{LISÍSTRATA IN LISÍSTRATA DE ARISTÓFANES}

\section{(V. 90-180)}

CONTEXTUALIZAÇÃO

Lisístrata, como a maioria das comédias conhecidas de Aristófanes, tem um tema político. A protagonista da peça homônima junta-se a outras mulheres gregas para organizar uma greve de sexo a fim de convencer os homens a acabar com a guerra. $\mathrm{O}$ trecho traduzido reproduz a insatisfação das mulheres pela ausência do companheiro devido às atividades bélicas. Lisístrata propõe, então, a estra tégia, que de início é rejeitada pela maioria, devido à importância que o sexo tem na vida dessas mulheres. Entretanto, todas entendem que vale a pena o sacrifício pessoal pelo bem maior, que é a paz.

O gosto e a necessidade que elas demonstram pelo sexo e também pelo membro masculino (seja ele o do próprio marido ou um objeto de couro) é cômica até mesmo para o século XXI. Afinal, apesar de ter conquistado certa liberdade sexual, a mulher deste século ainda é criticada ao agir como as personagens da comédia. 


\section{NAMIIIT $\Omega$}

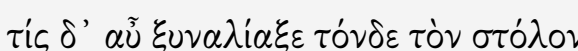

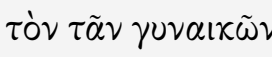

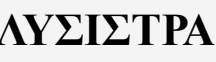

$\ddot{\eta} \delta^{\prime} \dot{\varepsilon} \gamma \omega \dot{ }$.

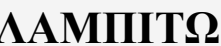

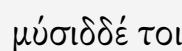

ö $\tau \iota \lambda \tilde{n} c \pi \circ \theta^{\prime} \dot{\alpha} \mu \dot{\varepsilon}$.

\section{KAAONIKH}

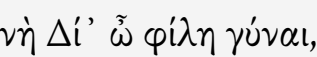

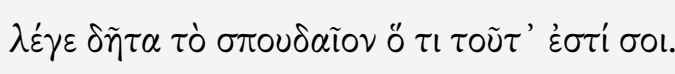

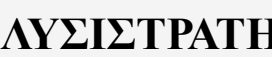

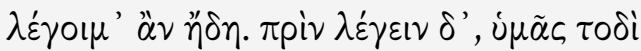

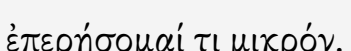

\section{KA $\Lambda$ ONIKH}

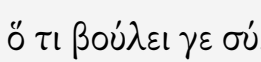

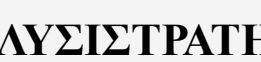

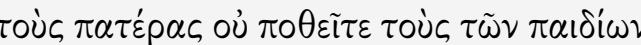

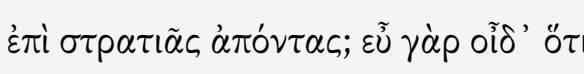

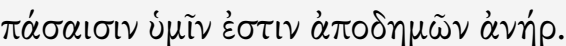

\section{LAMPITO}

E quem reuniu esta tropa

esta das mulheres?

\section{LISÍSTRATA}

Aqui eu.

\section{LAMPITO}

Fala então

o que deseja de nós.

\section{CLEONICE}

Sim, por Zeus! Ô a miga,

fala o que é tão sério pra você.

\section{LISÍSTRATA}

Falaria agora. Mas antes de falar pra vocês isso aqui,

vou perguntar uma coisinha.

\section{CLEONICE}

O que você quiser, ué

\section{LISÍSTRATA}

Os pais dos seus filhos, vocês não sentem falta deles, já que estão no exército?

Porque eu sei que, na verdade, o marido de todas vocês estão fora de casa. 


\section{KAMONIKH}

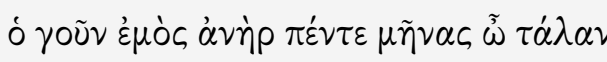

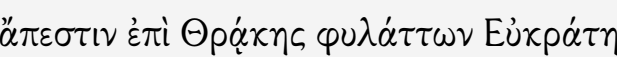

\section{MYPPINH}

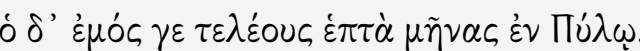

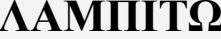

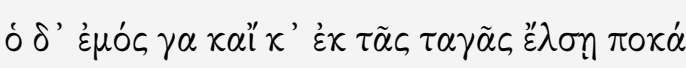

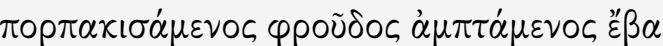

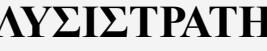

aे $\lambda \lambda^{\prime}$ o

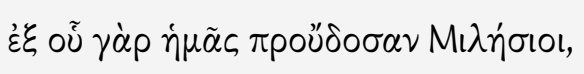

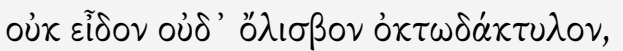

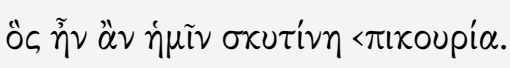

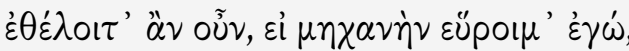

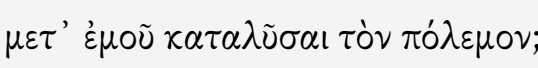

\section{KA AONIKH}

\section{$v \dot{\eta} \tau \dot{\omega} \theta \varepsilon \dot{\omega}$.}

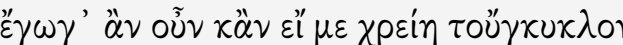

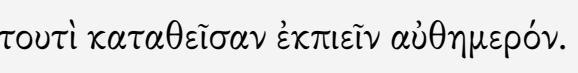

\section{CLEONICE}

Há pelo menos cinco luas, o meu homem - estou mal -

está na Trácia vigiando Eucrates.

\section{MIRRINA}

E o meu já está há sete luas completas em Pilos.

\section{LAMPITO}

E o meu, quando veio da chefia,

pegou o escudo e já foi embora voando.

\section{LISISTRATA}

Mas não sobrou nenhum pedaço de amante.

Porque nem quando os milésios nos abandonaram

fiquei sem ver pênis de oito polegares,

o que seria pra nós o auxílio de couro

Então, vocês querem que eu ache um instrumento que pode,

na minha opinião, acabar com a guerra?

\section{CLEONICE}

Sim, pelos deuses!

Ainda que eu mesma tivesse que esta minha [blusa

arrancar, ou que beber tudo de uma vez. 


\section{MYPPINH}

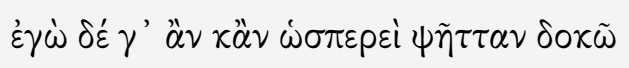

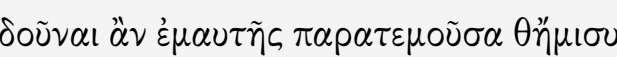

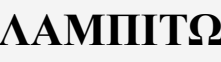

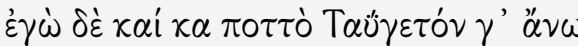

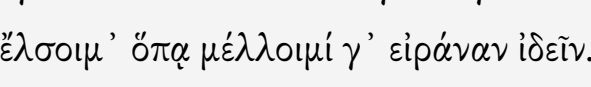

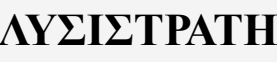

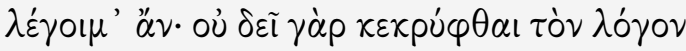

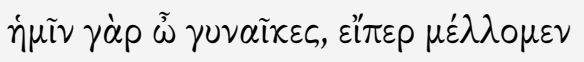

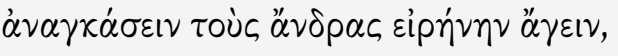

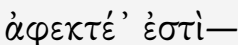

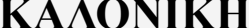

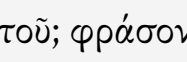

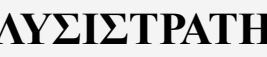

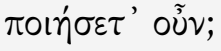

\section{KAMONIKH}

$\pi \circ i \dot{\sigma} \sigma o \mu \varepsilon v, x \ddot{\alpha} \nu \dot{\alpha} \pi \circ \theta \alpha \nu \varepsilon \tilde{\nu} \dot{\eta} \mu \tilde{\alpha} c, \delta \dot{\alpha} \eta$
MIRRINA

E eu até ficaria que nem um linguado

e daria a metade cortada de mim mesma.

\section{LAMPITO}

E eu ta mbém subiria até o Taigeto,

iria aonde fosse necessário só pra ver a paz.

\section{LISÍSTRATA}

Vou dizer, porque não é mais necessário [esconder o assunto.

Porque nós, ô mulheres, se quisermos mesmo

forçar os homens a trazer a paz,

seja mos abstinentes.

Cleonice

Quê? Explica.

\section{LISISTRATA}

Então vocês vão fazer?

\section{CLEONICE}

Vamos fazer, até se precisássemos morrer. 


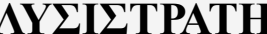

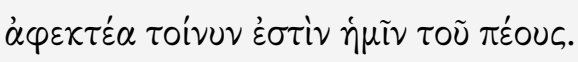

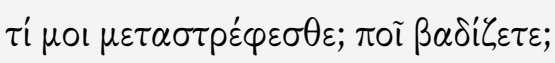

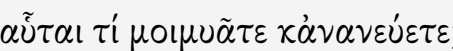

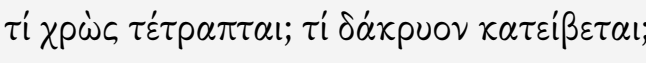

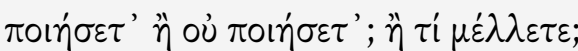

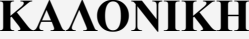

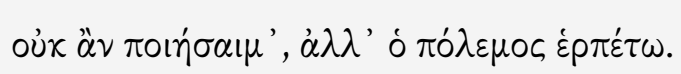

MYPPINH

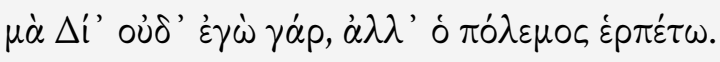

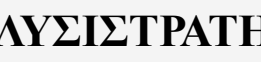

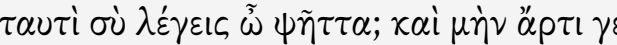

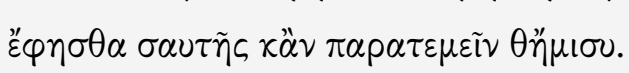

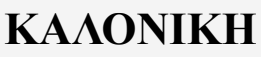

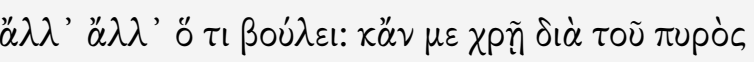

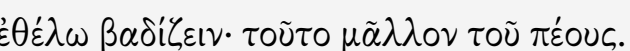

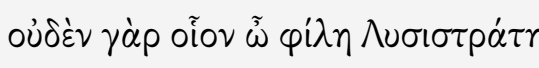

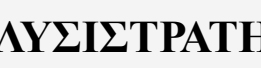

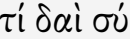

\section{LISÍSTRATA}

Sejamos abstinentes, então, da piroca.

Por que vocês me dão as costas? Pra onde [andam?

Por que comprimem os lábios e negam com a [cabeça?

Por que mudou a cor da pele? Por que choram?

Vocês vão fazer ou não? O que vocês querem?

\section{CLEONICE}

Não posso fazer isso, que a guerra continue.

\section{MIRRINA}

Por Zeus, porque nem eu, que a guerra continue.

\section{LISÍSTRATA}

O que você tá falando, ô linguado? E agorinha [mesmo você declarou que ia se cortar ao meio.

\section{CLEONICE}

Mas... mas... vê isso que você escolhe! Se [precisar, pelo fogo

eu vou andar: isso é mais que a piroca.

Porque nada é como ela, ô Lisístrata querida.

\section{LISÍSTRATA}

Você o quê? 


\section{MYPPINH}

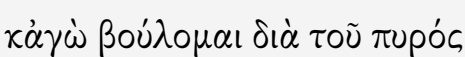

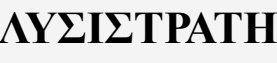

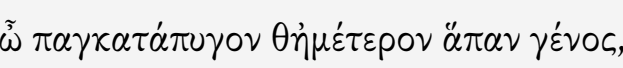

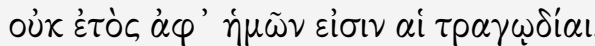

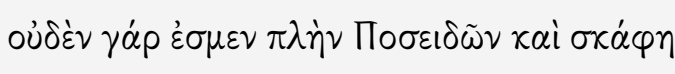

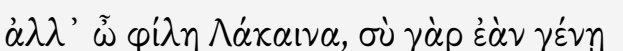

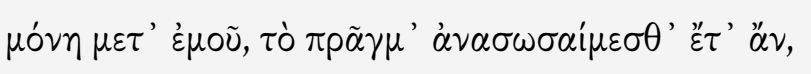

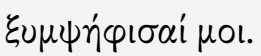

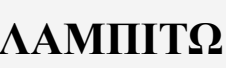

$\chi \alpha \lambda \varepsilon \pi \dot{\alpha} \mu \dot{\varepsilon} v$ vai $\tau \dot{\omega} \sigma i \dot{\omega}$

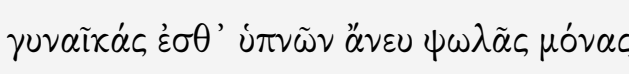

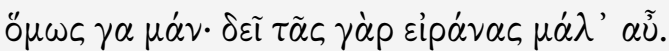

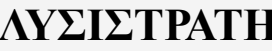

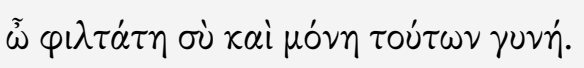

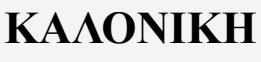

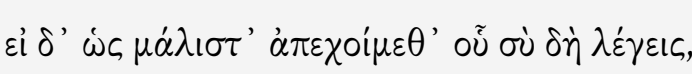

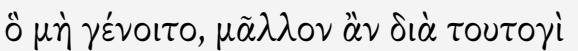

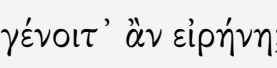

\section{MIRRINA}

E eu escolho o fogo.

\section{LISÍSTRATA}

Ô nossa raça toda indecente!

Não é à toa que as tragédias são sobre nós.

Porque não somos nada, só Poseidon e barco - [sexo e filhos.

Mas, ô querida lacônica, porque se estiver

só você comigo, a tarefa podemos ainda

resgatar,

conta comigo.

\section{LAMPITO}

É bem difícil - pelos deuses! -

pras mulheres dormirem sozinhas sem o caralho.

Mas que seja, porque a paz é muito necessária de [novo.

\section{LISÍSTRATA}

Ô queridíssima, e você é uma mulher única entre [essas!

\section{CLEONICE}

E se eu fico superabstinente, como você diz,

o que vai acontecer? Muito por causa disso

pode acontecer a paz? 


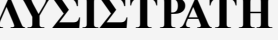

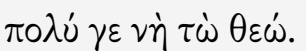

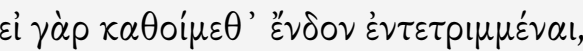

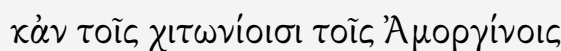

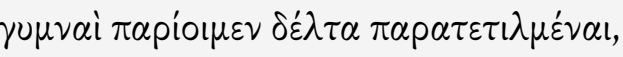

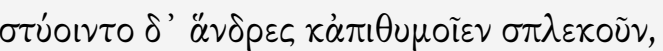

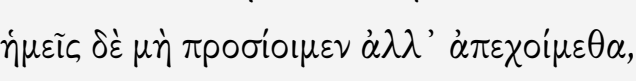

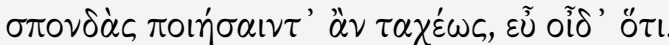

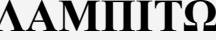

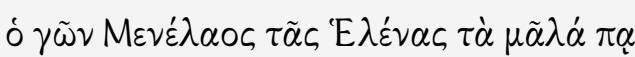

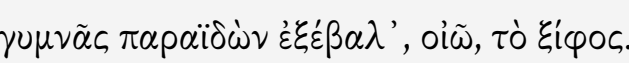

\section{KAAONIKH}

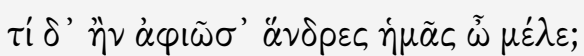

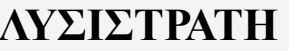

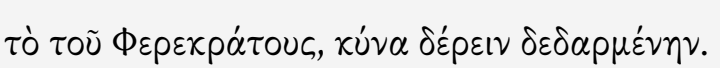

\section{KAAONIKH}

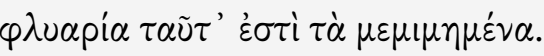

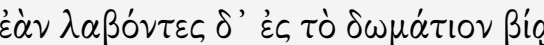

$\ddot{\varepsilon} \lambda \times \omega \sigma i \nu \dot{\eta} \mu \tilde{\alpha} c ;$

\section{LISÍSTRATA}

Muito, pelos deuses:

Pois se nos sentamos do lado de dentro [maquiadas

com os vestidos de Amorgos,

e se estivermos nuas e depiladas em forma de [delta,

os homens ficam com o pau duro e desejam [transar,

e nós estaremos lá, mas estaremos abstinentes,

e rápido eles podem fazer uma trégua, isso eu [bem sei.

\section{LAMPITO}

Com certeza quando Menelau percebeu os seios [da Helena nus, eu acho que ele largou a espada.

\section{CLEONICE}

E se os homens desistem de nós, ô meu bem?

\section{LISISTRATA}

Como diz Ferécrates, que esfolem o cãozinho [esfolado deles.

\section{CLEONICE}

Esses ditos são bobagem

E se eles levam pra cama à força

e nos violentam? 


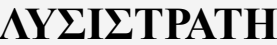

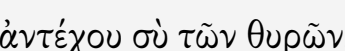

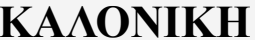

$\dot{\varepsilon} \alpha \nu \delta \dot{\varepsilon} \tau \dot{v} \pi \tau \omega \sigma \nu ;$

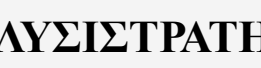

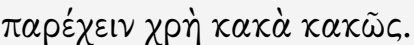

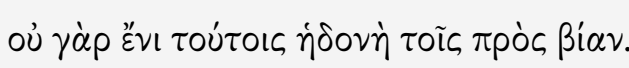

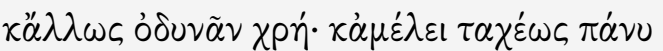

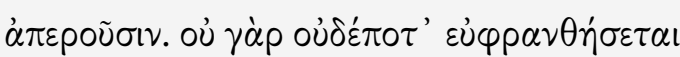

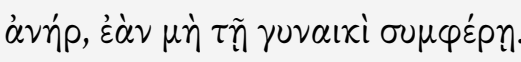

\section{KAMONIKH}

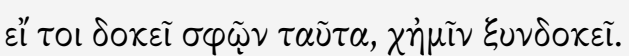

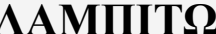

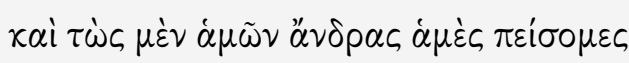

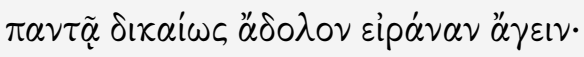

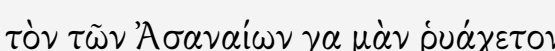

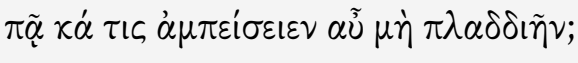

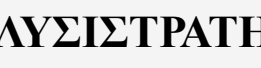

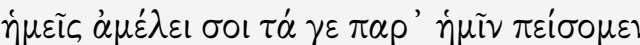

\section{LISISTRATA}

Você agarra na porta.

\section{CLEONICE}

E se baterem?

\section{LISÍSTRATA}

É preciso fazer mal e com má vontade.

Porque não há prazer nessas coisas à força.

Com boa vontade é preciso causar dor! E não [liga se rapidinho

eles forem embora. Porque não, nunquinha, vai [se diverti

um homem se ele não concordar com a mulher.

Cleonice

Se isso é bom pra vocês duas, pra nós também é.

\section{LAMPITO}

E nós vamos persuadir os nossos homens

a lutar de todo modo, com justiça, por uma paz [honesta!

Já a multidão instável dos atenienses

como convencer mesmo de que não estamos [brincando?

\section{LISISTTRATA}

Fica tranquila que nós vamos persuadir pro [nosso lado. 


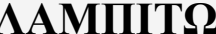

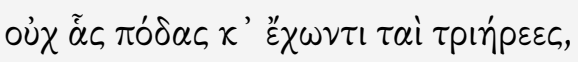

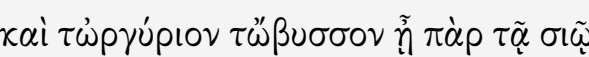

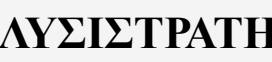

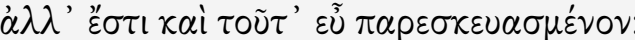

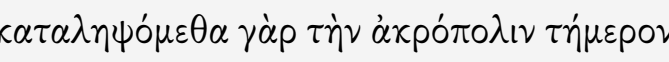

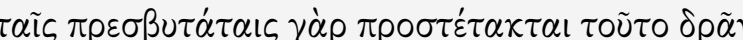

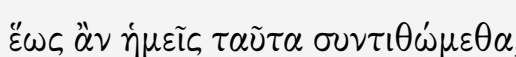

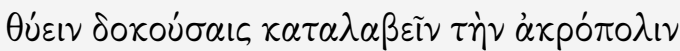

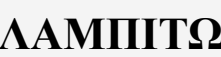

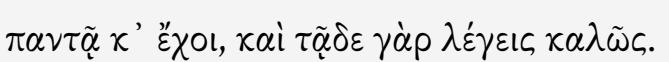

\section{LAMPITO}

Barcos de três remos não podem ter os pés,

e não pode haver dinheiro sem fim da parte dos [deuses.

\section{LISÍSTRATA}

Mas isso na verdade também já está preparado!

Porque va mos invadir a acrópole hoje.

Então ordenei às mais velhas que façam isso,

e nós já até concorda mos:

elas, fingindo fazer um sacrifício, vão invadir a [acrópole.

\section{LAMPITO}

Tudo pode dar certo, porque você falou bem [essas coisas. 


\section{REFERÊNCIAS}

ARISTÓFANES. Lisístrata. In: ARISTÓFANES. Comedias. Lisístrata Las Tesmoforias, Las Ranas, La Asamblea de las Mujeres, Pluto. Trad. L. M. M. Aparicio. Madrid: Editorial Gredos, 2007, p. 9-104.

ARISTÓFANES. A Greve do Sexo - Lisístrata. Trad. Millôr Fernandes, $1^{\mathrm{a}}$. edição. Porto Alegre: L\&PM, 2003.

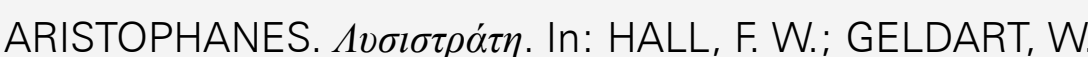
M. Aristophanes Comoediae. Ed. v. 2. Oxford: Clarendon Press, 1907. In: <http://www.perseus.tufts.edu/hopper/ text? doc $=$ Perseus\%3atext\%3a1999.01.0035> Acesso em 8 nov 2016

BRITTO, Paulo Henriques. Poesia: criação e tradução. Ipotesi, v. 12 , n. 2, p. 11-17, 2008

EURIPIDE. Euripide. Vol. 6. Ed. Louis Méridier. Paris: Les Belles Lettres. 1965-75.

EURÍPIDES. As Troianas. Introdução, tradução e notas de Maria Helena da Rocha Pereira. 1. ed. Lisboa: Edições 70, 1996.

\section{EURÍPIDES. Duas tragédias gregas: Hécuba e Troianas.}

Tradução e introdução de Christian Werner. 1. ed. São Paulo: Martins Fontes, 2004

EURIPIDES. Euripides: In Four Volumes (IV). Ion. Hippolytus. Medea. Alcestis. With an English translation by Arthur S. Way. London; New York: William Heinemann; Putnam's Sons, 1928.

EURIPIDES. Euripidis fabulae. V.3. Ed. J. Diggle. Oxford Clarendon Press, 1994.
EURIPIDES. Euripidis fabulae. Vol. 3. Gilbert Murray. Oxford. Clarendon Press, Oxford. 1913

EURIPIDES. Hipólito. Ed. bilíngue; posfácio e notas de Trajano Vieira; ensaio de Bernard Knox. São Paulo: Editora 34, 2015.

GRIMAL, Pierre. Dicionário da mitologia grega e romana. Tradução de Victor Jabouille. Rio de Janeiro: Bertrand Brasil, 2005.

MESCHONNIC, Henri. Linguagem, ritmo e vida. Extratos traduzidos por Cristiano Florentino. Revisão de Sônia Queiroz. Belo Horizonte: FALE/UFMG, 2006.

PAVIS, Patrice. Para uma especificidade da tradução teatral. In: PAVIS, Patrice. Teatro Cruzamento de Culturas. Tradução Nancy Fernandes. São Paulo: Perspectiva, 2008, p. 123-154.

\section{RACINE, Jean. Oeuvres de Jean Racine, précédées des} Mémoires sur sa vie, par Louis Racine. Paris: Didot, 1854 p. 241-261. Disponível em: https://fr.wikisource.org/wiki/ Ph\%C3\%A8dre_(Racine),_Didot,_1854\#Sc.C3.A8ne_III. Acesso em: 02 de ago. 2016.

SARTRE, Jean-Paul. As troianas (adaptado de Eurípedes)

Tradução de Helena Cidade Moura. 1. ed. Lisboa: Plátano, 1973.

SENECA. Tragoediae. Ed. R. Peiper ; G. Richter. Leipzig: Teubner, 1921 SÓFOCLES. Sophocle. Ed. A. Dain; P. Mazon. Paris: Les Belles Lettres, 1967.

Recebido em: 12-04-2019. Aceito em: 08-05-2019. 